\title{
MITOS PENCIPTAAN PADA SERAT PURWAKANDHA BRANTAKUSUMAN DAN POTENSI KAJIAN FILSAFATNYA
}

\section{Sartini}

Fakultas Filsafat Universitas Gadjah Mada

Email: $\underline{\text { tini-sartini@ugm.ac.id }}$

\section{Luwiyanto}

Program Studi Pendidikan Bahasa dan Sastra Daerah FKIP Universitas Widya Dharma

\section{Abstrak}

Tulisan ini bertujuan untuk mengkaji mitos penciptaan dalam Serat Purwakandha Brantakusuman (SPB), bagaimana kekhasannya dibandingkan dengan mitos-mitos di Indonesia dan teori mitos yang ada, dan menjelaskan tema-tema filsafati yang dapat dikaji dari mitos tersebut. Harapannya, kajian ini memberi kontribusi pada teori-teori mitos yang sudah ada. Tulisan ini merupakan kajian pustaka dengan objek buku/teks, laporan hasil penelitian, jurnal, dan sumber-sumber lain. Analisis dilakukan dengan interpretasi, koherensi-holistik, deskripsi, dan analisissintesis. Kerangka teori yang dipakai adalah teori mitos C A. Van Peursen dan Clifford Geertz. Hasil kajian menunjukkan bahwa mitos penciptaan tetumbuhan dalam SPB berlatar cerita kematian Dewi Tisnawati yang dibuang ke bumi. Kajian mitos tentang asal-usul tetumbuhan merupakan hal baru karena penelitian yang mengkaji mitos terkait pertanian dan Dewi Sri, pengaruh mitos dalam kehidupan dan aktivitas manusia, bentukbentuk ritual dan aktivitas sosial-budaya, serta hubungan antara mitos dan kesenian, lebih banyak terkait dengan asal-usul suatu tempat. Mitos dalam $S P B$ dan mitos-mitos di Indonesia berkontribusi mendukung konsepkonsep mitos yang sudah dijelaskan para pemikir besar. Mitos penciptaan dan mitos-mitos yang lain dalam SPB dapat menjadi bahan kajian dari perspektif cabang-cabang filsafat dan substansi konsepnya dapat dikritisi dengan kajian kritis filsafati.

Kata kunci: Purwakandha-Brantakusuman, mitos, penciptaan, filsafat. 


\section{Abstract}

This article examines the creation myth in Serat Purwakandha Brantakusuman (SPB), how its characteristics are compared to myths in Indonesia and existing mythical theories, and explains philosophical themes that can be examined from these myths in order to give its theoretical contributions in existing mythical theories. It is a literature study by reviewing books texts, research reports, journals, and other sources. The analysis is done by interpretation, coherence-holistic, description, and analysis-synthesis. The theoretical framework used is the myth theory C A. Van Peursen and Clifford Geertz. The results of the study indicate that the myth of the creation of plants in SPB is based on the story of the death of Dewi Tisnawati who was banished to earth. The study of myths about the origin of plants is new because research examining myths related to agriculture and Dewi Sri, the influence of myths in life and human activities, forms of rituals and socio-cultural activities, and the relationship between myths and art, are more related to origin place. The myths in SPB and myths in Indonesia contribute to supporting myth concepts that have been described by great thinkers. The creation myth and other myths in the $S P B$ can be subject to study from the perspective of the branches of philosophy and its conceptual substances can also be criticized philosophically.

Keywords: Purwakandha-Brantakusuman, myth, creation, philosophy.

\section{PENDAHULUAN}

Istilah mitos sering ditemukan dalam banyak perbincangan khalayak umum maupun akademisi. Penjelasan mengenai konsep mitos pun sangat kompleks. Variasi ini sebagaimana nampak dalam penelitian yang dilakukan oleh beberapa peneliti Indonesia (Sartini, 2016). Mitos juga sering dikaitkan dengan penciptaan alam yang biasanya berupa semacam cerita khayal. Meskipun demikian, mitos-mitos tersebut dipercaya dan mempengaruhi bawah sadar pemikiran manusia, terbukti banyak kelompok masyarakat yang pola hidupnya dikendalikan oleh mitos tersebut. Hal ini sebagaimana para ahli menjelaskan mitos tersebut. Belum ditemukan penelitian yang secara khusus mengkaji mitos 
penciptaan, khususnya flora dan fauna. Menarik untuk diteliti bagaimana letak konsep mitos ini di antara kajian-kajian yang sudah ada dan bagaimana konten mitos ini memungkinkan untuk dikaji dalam fokus kajian filsafat.

Materi artikel ini adalah hasil penelitian tentang mitos flora dan fauna dalam SPB khususnya pada Pupuh XVI-XXXIII. SPB yang dijelaskan di sini adalah teks yang berisi tentang cerita Ramayana yang menjadi salah satu babon cerita wayang purwa di Jawa (Luwiyanto, 2018). Penelitian dilakukan dengan beberapa unsur metodis: interpretasi, koherensi internal dan holistik, deskripsi dan analisis-sintesis (Bakker dan Zubair, 1994). Interpretasi juga dipahami sebagai pembacaan secara cermat untuk mendapatkan arti, nilai dan maksud manusiawinya (Bakker dan Zubair, 1994). Pembacaan atas makna teks dilakukan dengan melihat isi keseluruhan, selanjutnya data dideskripsikan dan dianalisissintesis untuk mendapatkan kesimpulan.

Ditemukan penelitian mitos tentang profil Ki Ageng Gribig yang mendeskripsikan mitos dan pengaruhnya terhadap masyarakat sekitar dan para peziarah (Rachman dan Roekhan, 2012). Mitos juga dikaitkan dengan larangan di masyarakat, sebagaimana kajian yang menginventarisasi mitos di masyarakat Puluik-Puluik Selatan (Arlin, 2014). Diyah Kumalasari mengkaji mitos petilasan pewayangan di pegunungan Rahtawu Kudus dan mitos profil Semar yang dipercaya dapat berkomunikasi dan dimintai bantuan (Kumalasari, 2010). Inawati Dewi mengkaji unsur-unsur pendidikan Islam dalam mitos Jawa yang menyimpulkan bahwa di dalam mitos-mitos yang dipercayai orang Jawa terdapat nilai-nilai pendidikan tauhid, ibadah dan akhlak (Inawati, 2013). Penelitian ini senada tentang nilai pendidikan Islam dalam mitos dan perkataan Jawa. Mitos dalam perkataan Jawa mengandung nilai insani, akhlak, ibadah, dan syariah (Jannah, 2013).

Kajian mitos lainnya berkaitan dengan Dewi Sri sebagaimana pernah dikaji oleh Sartini (2012) yang menjelaskan tentang mitos Dewi Sri dan kaitannya dengan musik dan kesenian tradisional 
yang banyak berkembang di masyarakat petani di Jawa atau bahkan Indonesia. Selain itu terdapat kajian tentang filosofi Dewi Sri sebagai sumber ide penciptaan seni kriya keramik yang berbentuk kendi yang merupakan wujud nilai filosofis Dewi Sri sebagai pembawa berkah (Waryanti, 2015). Mitos Dewi Sri juga dikaitkan dengan rempah-rempah. Dewi Sri dipercaya menurunkan tanaman di bumi dan akhirnya memberikan inspirasi kepada para wanita ikut menyokong kehidupan keluarga dengan berdagang rempahrempah (Lestari, 1996).

Mitos yang dibahas para pemikir dunia lebih banyak menjelaskan mengenai fungsi mitos itu sendiri, tentang bagaimana mitos-mitos tersebut berfungsi mempengaruhi kehidupan manusia. Dari kajian pemikiran mitos Mircea Eiade, Roland Barthes, William Bascom, Joseph Campbell, Clyde Levi-Strauss, dan C. A. Van Peursen disimpulkan bahwa mitos merupakan simbol dalam bentuk cerita yang berkembang di dalam masyarakat sepanjang sejarah. Mitos juga berkaitan dengan bahasa dan berkaitan dengan komunikasi, makna dan pesan. Mitos mengandung unsur kepercayaan dan berfungsi mengarahkan manusia dalam hidupnya. Mitos kuno berkaitan dengan kepercayaan yang hidup di masyarakat. Mitos ikut mengarahkan bagaimana kebudayaan suatu masyarakat terbentuk (Sartini, 2016). Di dalam menghasilkan kesimpulan tersebut, para pemikir memaparkan contoh-contoh mitos yang diamatinya. Sejauh pengamatan peneliti, belum ada pemikir yang menjelaskan mitos yang bersumber dari naskah, terlebih terkait dengan konsep penciptaan flora dan fauna.

Dasar teoritik penelitian ini adalah bahwa mitos merupakan bagian dari kebudayaan dan bakat manusiawi manusia. Mitos dapat berupa cerita yang memberikan pedoman dan arah tertentu, sebagai pedoman kebijaksanaan dari suatu kehidupan kolektif masyarakat tertentu (Peursen, 1992). Mitos juga berhubungan dengan kepercayaan yang ada di masyarakat termasuk di dalamnya agama (Geertz, 1993) dan bahwa agama merupakan sistem simbol yang mampu mengarahkan tujuan, membangun suasana hati, memotivasi, merumuskan tatanan kehidupan, yang kemudian 
memunculkan suatu realitas unik (Fitria, 2012). Kajian filsafati dimaknai sebagai tema-tema kajian fundamental yang dapat ditelusuri dari bidang-bidang kajian filsafat sistematik maupun cabang-cabang filsafat dan sebagai bentuk penalaran melalui pemahaman, kritik, dan penilaian suatu pengetahuan untuk mendapatkan hakikat terdalam dari suatu pengetahuan (Kattsoff, 1996).

Kajian ini difokuskan untuk mengkaji mitos penciptaan dalam SPB, meneliti dan meletakkannya di antara kajian mitos dan teori mitos yang sudah ada, dan menelisik tema-tema filsafati yang dapat dikaji dari mitos SPB. Tujuannya adalah untuk menjelaskan kontribusi penelitian ini dalam perkembangan kajian dan teori mitos.

\section{MITOS DI INDONESIA}

Mitos sering dihubungkan dengan hal tempo dulu, warisan nenek moyang, tidak rasional, sesuatu yang begitu saja dipercaya tetapi berperan menggerakkan masyarakat. Atas dasar mitos, masyarakat melakukan atau tidak melakukan sesuatu. Hal ini disebabkan karena adanya ketakutan akan hal-hal yang mungkin terjadi bila melanggar apa yang dipercaya tersebut. Kedua hal ini senada dengan pandangan bahwa mitos adalah konsep metafisis dunia kuno untuk menggambarkan kehidupan sehari-hari. Kehidupan sehari-hari adalah cerminan konsep metafisis kuno tersebut. Kepercayaan atas konsep tersebut mengarahkan pada perilaku tertentu. Fungsi mitos disetarakan dengan fungsi simbol, ritus, atau ucapan, yang menunjukkan kesadaran manusia akan situasi tertentu di dalam kosmos yang mengakibatkan sikap metafisis tertentu (Mircea, 2002). Menurut Peursen, pada dasarnya mitos merupakan bagian dari kebudayaan dan merupakan bakat manusiawi manusia. Sudah terlahir dalam kodratnya bahwa manusia hidup bersama mitos-mitos. Mitos tersebut dapat berupa cerita yang memberikan pedoman dan arah tertentu, sebagai pedoman kebijaksanaan dari suatu kehidupan kolektif masyarakat tertentu (Peursen, 1992). 
Mitos mengandung unsur kepercayaan. Kepercayaan, religi, atau agama merupakan bagian dari kehidupan dan kebudayaan suatu masyarakat (Sutrisno, 2008). Agama bahkan merupakan suatu sistem simbol yang mampu mengarahkan tujuan, membangun suasana hati, memotivasi, merumuskan tatanan kehidupan, yang kemudian memunculkan suatu realitas unik (Geertz, 1993). Mitos, kepercayaan, religi atau agama dan kebudayaan secara luas memberi dasar pandangan, suasana dan mengarahkan kehidupan masyarakat. Mitos dan kebudayaan berkembang sejalan dengan sejarah masyarakat itu sendiri.

Mitos di Indonesia disinyalir sudah berkembang sejak awal kedatangan agama Islam sampai sekitar akhir tahun 1800 Masehi yang dicirikan dengan kehidupan religio-magis. Pada masa tersebut kehidupan agama, baik menyangkut doktrin, ritus, maupun ide-ide keagamaan masih diselimuti mitos. Mitos pada saat itu berfungsi sebagai strategi yang efektif untuk memperteguh keyakinan religius. Kehidupan beragama yang diselimuti dengan mitos-mitos tersebut bisanya ditampakkan dengan praktik-praktik keagamaan yang irrasional (tidak masuk akal) tetapi memiliki fungsi yang rasional (Masroer, 2004). Apakah mitos-mitos sebagaimana yang pernah ada dan dipercayai masyarakat jauh sebelum jaman dewasa ini masih hidup sampai saat ini?

Berdasarkan data kajian-kajian para peneliti, ternyata masyarakat Indonesia masih mempercayai mitos-mitos. Banyak tradisi dan ritual di masyarakat sekarang yang berbasis pada mitos. Sebagai contoh, ritual pembukaan cupu Kyai Panjolo, merupakan salah satu kegiatan yang dikelilingi mitos. Tradisi ritualnya masih dilakukan sampai sekarang. Banyak anggota masyarakat mempercayai, bertindak, dan berlaku, sebagaimana mitos yang diisyaratkan dari ritual tersebut (Suciani, 2015).

Mitos lain adalah mitos Dewi Sri, dewi kesuburan dengan berbagai variasi namanya. Mitos Dewi Sri, masih menjadi dasar pandangan hidup masyarakat di berbagai daerah di Indonesia (Sartini, 2012). Di berbagai masyarakat agraris terdapat 
kepercayaan bahwa tanaman berasal dari tubuh seorang wanita (Hartati, 2012).

Di Sunda, profil setara Dewi Sri disebut Nyi Pohaci Sanghyang Sri, dan di Flores disebut Ine Pane atau Ine Mbu. Mitos ini bercerita tentang seorang gadis yang atas permintaannya mengorbankan diri sehingga dari tubuhnya tumbuh tanaman padi. Di Minangkabau, dikenal istilah Saningsari atau Induang Padi dan di etnik Tomori Tanah Toraja dikenal dengan nama Ineno Pae dan berperan sebagai penjamin tumbuh suburnya padi. Di etnik Lio Flores Tengah dikenal dengan Ine Pare. Keberadaannya sering disimbolisasikan dan dihubungkan dengan berbagai upacara dan bentuk kesenian tradisional yang dilakukan oleh para petani (Daeng, 2012). Berdasar beberapa sumber yang disebutkan, ternyata mitos Dewi Sri terdapat di hampir semua wilayah di Indonesia, dari Barat sampai Timur Indonesia dengan berbagai variasi nama. Menarik juga untuk dikaji bagaimana sebaran mitos dan kaitan sosio kulturalnya pada masyarakat masing-masing karena bentuk ekspresinya di masyarakat cukup beragam.

Di beberapa bagian wilayah Jawa, mitos Dewi Sri muncul dalam berbagai bentuk kesenian. Di Yogyakarta muncul dalam wayang. Cerita Dewi Sri biasanya dipagelarkan pada acara Bersih Desa. Tari Seblang di Banyuwangi, Lengger, Sintren dan lainnya juga merupakan simbolisasi Dewi Sri. Jenis kesenian terkait dengan mitos juga muncul pada musik tradicional Rinding Gumbeng di Gunungkidul Yogya, juga Karinding, Tarawangsa, dan Angklung yang banyak dimainkan pada upacara Seren Taun di Jawa Barat (Sartini, 2012).

Mitos tidak hanya menyebar dalam alam bawah sadar, cerita masyarakat, ritual dan seni, tetapi mitos juga tergambarkan dalam teks dalam berbagai bentuknya. Boleh jadi, naskah merupakan gambaran atau cerminan pandangan masyarakat itu sendiri. Sebaliknya, naskah juga dapat menjadi rujukan dan sumber cerita yang berkembang di masyarakat. Salah satu contohnya adalah mitos penciptaan yang terdapat di dalam naskah SPB yang menjadi objek kajian ini. Cerita mitos tersebut tidak berada dalam cerita 
tersendiri melainkan menjadi bagian dari hamparan cerita mitos lainnya.

\section{MITOS DALAM SERAT PURWAKANDHA BRANTAKUSUMAN}

SPB merupakan salah satu produk karya sastra yang berisi banyak ragam cerita antara lain cerita tentang para dewa, mitos tentang gunung, hewan, tumbuhan, cerita Ramayana, dan cerita para raja di Jawa. Teks ini merupakan teks besar yang merupakan salah satu sumber cerita wayang purwa selain teks Pustaka Raja Purwa. Naskah tersebut bertuliskan dengan huruf Jawa, berbentuk tembang macapat dan berbahasa Jawa Baru (Luwiyanto, 2018). Mitos tumbuhan yang akan dikaji terdapat dalam Pupuh XVIXXXIII. Sesungguhnya di dalam teks terdapat banyak mitos yang berhubungan dengan keberadaan Dewi Sri, tetapi dalam paparan berikut hanya dijelaskan cerita mitos yang paling terkait dengan penciptaan tumbuhan. Mitos-mitos yang lain dijelaskan sebagai alternatif kajian mitos yang dapat digali dari SPB.

\section{Mitos Dewi Tisnawati dan Munculnya Tetumbuhan}

Cerita kematian Dewi Tisnawati inilah yang terkait dengan munculnya tetumbuhan di bumi. Kemunculan tetumbuhan di bumi tersebut sebagai akibat kematian Dewi Tisnawati, yang masih bersemayam di khayangan, yang disebabkan oleh perasaan sedih hati yang mendalam akibat ulah utusan yang ditugaskan mencari persyaratan lamaran Batara Guru pada Dewi Tisnawati. Di dalam cerita ini terdapat hubungan sebab-akibat antara apa yang terjadi di kahyangan dan apa yang kemudian terjadi di bumi.

Batara Guru mengutus Kalagumarang untuk memenuhi persyaratan penerimaan lamaran yang diminta Dewi Tisnawati. Akan tetapi ternyata Kalagumarang bertindak tidak sebagaimana yang diharapkan baik oleh Batara Guru maupun Dewi Tisnawati. Kepercayaan yang diberikan Batara Guru disalahgunakan dengan memanfaatkan kewenangan dari Batara Guru untuk melakukan hal-hal yang tidak baik. Dalam perjalanannya di dunia, 
Kalagumarang mengejar-ngejar Dewi Sri untuk dijadikannya sebagai istri. Padahal, Dewi Sri adalah istri Batara Wisnu. Dewi Sri menolak keinginan Kalagumarang dan mengutuknya menjadi seekor babi hutan. Meskipun sudah menjadi babi hutan, sikap Kalagumarang semakin menjadi-jadi dan terus mengejar Dewi Sri. Akibatnya terjadilah perseteruan antara Kalagumarang dengan Batara Wisnu. Percekcokan antara Kalagumarang dengan Batara Wisnu berlangsung lama.

Sepak terjang utusan Kalagumarang yang tidak baik tersebut diketahui oleh Dewi Tisnawati di kahyangan. Dewi Tisnawati merasa kecewa dan sakit hati karena utusannya telah meresahkan masyarakat dunia. Dewi Tisnawati bersedih hati dan akhirnya meninggal dunia di atas pangkuan Batara Guru. Jasad Dewi Tisnawati kemudian dibawa turun ke dunia oleh Batara Brama dan diletakkan di hutan Kendayana di wilayah kerajaan Mendangkamolan. Mendangkamolan pada saat itu dipimpin oleh seorang raja bernama Maharaja Makukuhan.

Mendangkamulan menjadi tempat tumbuhnya tanaman karena selang beberapa hari setelah jasad Dewi Tisnawati diletakkan di hutan Kendayana, dari jasadnya tumbuhlah beraneka ragam tanaman. Dari bagian kepala tumbuh tanaman kelapa, pete, kemlandingan, jengkol, dan tanaman liar yang biasa hidup di hutan. Dari bagian telapak tangan tumbuhlah tanaman pisang, sedangkan dari bagian payudara tumbuh tanaman pepaya. Dari bagian gigi tumbuh tanaman jagung, dari bagian pusar tumbuh pohon aren, dari bagian hati tumbuh tanaman sawo dan tanjung, dan dari bagian mata tumbuh tanaman padi. Aneka tanaman tumbuh dari jasad mendiang Dewi Tisnawati dan akhirnya bermacam-macam tanaman tersebut tersebar dan tumbuh subur di wilayah Mendangkamolan.

Seterusnya diceritakan bahwa tanaman-tanaman tersebut dianggap istimewa dan kemudian dijadikan sebagai persembahan bagi para dewa. Oleh karena tanaman-tanaman tersebut dipahami sebagai milik dewa maka tanaman-tanaman tersebut harus dijaga oleh para dewa. 


\section{Mitos-mitos Lainnya}

Selain terdapat mitos penciptaan dengan meninggalnya Dewi Tisnawati dan munculnya tanaman di bumi, SPB juga memuat beberapa mitos lain seperti asal-usul Jawa, konsep dunia, konflik moral, asal-usul penataan kalender, dan lainnya. Cerita-cerita mitos tersebut dapat menjadi sumber kajian dari berbagai perspektif.

Pada cerita asal-usul ratu dan kerajaan pertama di Jawa, diceritakan bahwa Dyah Bermani merupakan seorang ratu wanita cantik anak dari Dewa Brahma yang memerintah kerajaan bernama Medangkamolan. Sejatinya, seorang raja wanita harus menikah untuk menurunkan penerus kerajaan. Sayangnya, Dyah Bermani tidak mau menikah dan keadaan ini menyebabkan prahara di kerajaannya yaitu banyak bencana yang meluluhlantakkan kerajaannya. Akhirnya, oleh Hyang Guru (Hyang Pramesthi), Dyah Bermani dikembalikan menjadi bidadari di surga dan digantikan adiknya yaitu Ratu Maharaja Dyah Bermaniwati. Raja baru ini menikah dengan Dewi Basuretna, anak Hyang Basuki. Dyah Bermaniwati terkenal dengan nama Mahaprabu Makukuhan. Makukuhan mengandung arti bertahta dengan sangat kuat. Negara ini menjadi besar. Prabu Bermaniwati inilah yang disebut sebagai raja pertama di Pulau Jawa, Medangkamolan. Adik iparnya, Jaka Puring, menjadi patihnya.

Mitos terkait konflik moral terdapat pada cerita Batara Guru yang mempunyai istri Dewi Uma. Ia mempunyai anak perempuan jelita yang merupakan anak jelmaan. Proses kelahirannya berakhir pada jatuhnya cupumanik yang kemudian pecah dan muncullah seorang bayi wanita yang kemudian diberi nama Dewi Tisnawati. Bayi Dewi Tisnawati tersebut dirawat oleh Batara Guru bersama dengan istrinya hingga menjadi seorang gadis cantik jelita. Konfil nilai terjadi ketika Batara Guru justru jatuh cinta kepada Dewi Tisnawati yang mulai menginjak remaja berusia 14 tahun. 
Mitos hewan perusak, terdapat pada cerita Pututjantaka. Suburnya tanaman di Medangkamolan ternyata menjadi sumber masalah karena ada pihak lain di kahyangan yang menginginkannya. Pututjantaka, seorang dewa yang menguasai dunia binatang, tergiur dengan tanaman padi yang subur tersebut. Kebetulan, pada saat yang sama di kahyangan terjadi musibah yang mengakibatkan para binatang kelaparan. Setelah mendengar berita tentang kesuburan tanaman tersebut maka Pututjantaka menganjurkan anak-anaknya yang berupa beraneka jenis binatang seperti: tikus, babi hutan, burung, banteng, ular, dan sebagainya, untuk turun ke dunia dan menuju persawahan di Mendangkamolan. Anak-anak Pututjantaka tersebut beramai-ramai mendatangi dan merusak persawahan padi yang sedang menguning di Mendangkamolan.

Mitos lain berkaitan dengan percintaan ibu-anak dan munculnya kalender. Tersebutlah nama seorang Resi. Resi Gana mempunyai seorang anak lelaki berwajah tampan dan berhati berhati mulia yang bernama Tritustha. Oleh sang resi, Tritustha diabdikan pada raja Makukuhan di Mendangkamolan. Keberuntungan datang ketika Tritustha lalu diambil menantu oleh raja dan kemudian sepeninggal raja ia menggantikan kedudukan raja yang mangkat. Tritustha mempunyai tiga orang anak, yaitu dua orang laki-laki dan yang terakhir seorang wanita, yaitu: Manumanangsa, Manumagdewa, dan Manumagwati. Di lingkungan keluarga, Resi Gana dikelilingi oleh dua pelayan (endang) yang cantik jelita, yaitu Dewi Sinta dan Dewi Landep.

Resi Gana yang sudah tua itu ternyata tergoda asmara dengan dua orang pelayan tersebut. Dua wanita pelayan tersebut sebenarnya tidak mau dilamarnya. Akan tetapi, pada suatu hari, dengan melalui mimpi, Dewi Sinta disetubuhi oleh Resi Gana lalu hamil. Buah kehamilan Dewi Sinta melahirkan seorang anak lakilaki yang tampan dan gagah perkasa. Anak tersebut kemudian diberi nama Watugunung. Sayangnya, ketampanan dan kegagahannya tidak sejalan dengan perilakunya. Sejak masih kecil, Watugunung mempunyai kebiasaan yang kurang baik yaitu suka 
makan berlebihan dan tidak pernah kenyang. Diberi makanan berapa pun banyaknya si Watugunung masih merasa kurang dan masih merasa lapar. Keadaan ini sering membuat ibunya marah dan jengkel. Sampailah pada suatu peristiwa yang membuat Watugunung harus berpisah dari ibunya. Sang ibu merasa jengkel pada Watugunung karena ia terus mengejar minta makan, sementara nasinya belum matang. Ibunya lalu memukul kepala Watugunung dengan enthong (sendok penanak nasi) hingga melukai kepalanya. Karena peristiwa tersebut, Watugunung lalu pergi meninggalkan rumah dan mengembara keluar-masuk hutan. Pengembaraannya berlangsung sampai ia dewasa. Watugunung kemudian tumbuh menjadi pemuda yang tampan, perkasa, dan sakti. Watugunung menjadi tokoh yang ditakuti oleh lawanlawannya. Ia juga mempunyai kekuasaan dengan menjadi raja di Gilingwesi. Kedewasaan dan kekuasaannya memunculkan keinginan untuk mencari dan mendapatkan pasangannya.

Kesohoran kecantikan dua pelayan (endang) Resi Gana, yakni Dewi Sinta dan Dewi Landep, sampailah ke telinga Watugunung. Atas adanya rasa penasaran terhadap kedua wanita pelayan cantik tersebut, Watugunung menyuruh patihnya untuk menghadirkan dan mendapatkan mereka. Perpisahan yang cukup lama antara Watugunung dengan ibunya, dan waktu itu Watugunung masih belum dewasa membuat mereka lupa tentang masa lalunya. Wajahnya pun sudah tidak saling dikenali karena sudah mulai berubah. Kedua wanita pelayan itu akhirnya dinikahi oleh Watugunung, dan dari pernikahan tersebut melahirkan keturunan. Pernikahan Watugunung dengan Dewi Sinta melahirkan dua puluh tujuh anak laki-laki. Dua puluh enam anak laki-lakinya tersebut lahir dalam keadaan kembar sepasang-sepasang. Sedangkan yang terakhir dilahirkan tidak kembar atau sendirian. Dari kelahiran yang pertama ke berikutnya terjadi secara periodik yaitu setiap tahun melahirkan anak. Dua puluh tujuh anak ditambah ibu, bibi, dan ayahnya, kemudian dijadikan nama-nama wuku. Di dalam bait-bait naskah tersebut tidak dijelaskan detail nama-nama wuku 
tersebut. Wuku (Pawukon) merupakan salah satu penghitungan kalender Jawa-Bali dengan siklus 210 hari (Couteau, 2010).

Versi cerita di Bali ditulis dengan mendasarkan pada sumber di Gedung Kirtya, Singaraja (Couteau, 2010). Di Bali nama-nama wuku tersebut diambil dari nama raja-raja yang menantang dan dikalahkan oleh Watugunung yang berkumlah 27, yaitu: Wukir, Kulantir, Taulu, Gumbreg, Wariga, Warigadian, Julungwangi, Sungsang, Dunggulan, Kuningan, Langkir, Medangsia, Pujut, Pahang, Krulut, Merakih, Tambir, Medangkungan, Matal, Uyeh, Menail, Perangbakat, Bala, Ugu, Wayang, Kulawu dan Dukut. Sebagai pemenang atas penyerahan diri raja-raja penantang ini, maka Watugunung menjadi raja di raja, raja raksasa di seluruh bumi (Couteau, 2010).

Di samping cerita mitos yang sudah dijelaskan, masih banyak cerita mitos yang dapat digali dari naskah SPB. Mitos Dewi Sri banyak ditemukan pada lingkungan masyarakat pertanian.

\section{MITOS DEWI SRI DI MASYARAKAT}

Mitos Dewi Sri tumbuh subur di masyarakat. Banyak hasil penelitian menunjukkan bahwa fungsi mitos menjadi salah satu referensi dalam kehidupan masyarakat di Indonesia. Hal ini tercermin pada upacara-upacara dan bahkan kesenian tradisional yang banyak dipergelarkan di masyarakat seperti wayang, musik tradisional, dan lainnya. Sumber ceritanya dapat berupa cerita lisan tetapi juga teks sebagai SPB. Selain SPB, setidaknya ditemukan dua naskah lain, yaitu Asal Mula Padi (dari Banyumas) yang termasuk dalam kumpulan cerita rakyat dan buku Sri Sadana yang menjadi sumber bacaan masyarakat. Kedua versi mitos Dewi Sri tersebut diyakini bersumber pada sastra lisan yang telah berkembang di masyarakat. Kedua teks tersebut memuat konsep kosmologi Jawa, pertanian dan petaninya. Simbolisasinya juga muncul dalam ritus perkawinan (midodareni), tata ruang (bangunan) dan ritus pertanian (Suwardi, tanpa tahun). Di dalam struktur berpikir Jawa, asal-usul benih kehidupan berasal dari dunia atas (dewa) yang diberikan pada dunia bawah (manusia). Fungsi ritus adalah untuk 
memastikan bahwa benih kehidupan tersebut tetap terjaga sebagai manifestasi hubungan dunia atas dan dunia bawah. Dewi Sri dipahami sebagai dewi yang bertugas memelihara tanaman tersebut (Sumintarsih, 2007).

Implementasi yang lain muncul dalam asesoris rumah yang berupa patung sepasang yang disebut Loro Blonyo, yang diyakini masyarakat pendukungnya sebagai bentuk pengharapan dan doa. Patung ini meruapakan representasi Dewi Sri dan Raden Sadana yang merupakan simbol kesuburan (biologis manusia dan tanaman) dan kemakmuran (Saputra, 2007). Dalam adat dan konstruksi rumah Jawa, patung ini dipasang di depan senthong tengah (kamar tengah). Hal ini berkaitan dengan fungsi magis dari bilik dalam konsep rumah Jawa (Joglo). Di dalam dunia modern, simbolisasi patung tersebut bahkan dipasang di perkantoran sebagai simbol harapan akan kemakmuran dan kesejahteraan. Makna keluarga diperluas. Tidak hanya dalam lingkup keluarga, patung loro blonyo mengandung makna keseimbangan dalam lingkungan sosial budaya dalam rangka keselaranan kosmis. Loro Blonyo adalah Dewi Sri dan Sadana yang dianggap titisan Syiwa dan Laksmi atau Wisnu dan Dewi Uma, menjadi Candra Kirana dan Inu Kertapati, atau Kamajaya dan Kamaratih. Simbolisme patung dimaknai sebagai sarana menyeimbangkan nilai sosial, dan menyelaraskan kosmis. Dewi Sri merupakan simbolisasi ibu yang melahirkan kesuburan tanaman dan Sadana melahirkan kepatutan sandang dan busana (Subiyantoro, 2009).

Di desa Mekar Wangi Saketi Pandeglang Jawa Barat, seni tradisional seperti Dodod atau Nanen (tanam dan panen padi) yang merupakan upacara khas petani dianggap sebagai suatu bentuk pengkultusan pada Sang Hyang Dewi Sri (Dewi Sri) atau leluhur mereka Nyi Pohaci Sanghyang Sri. Upacara ini meliputi unsur tatanen (mengawali tanam padi), ngalaksa (upacara pada saat tanaman padi tumbuh), dan rasulan (upacara pada saat panen dan menyimpan padi ke lumbung/leuit) (Yuliawan, tanpa tahun). Masyarakat pertanian di daerah lain mempunyai variasi ritual dan musik tradisional yang memiliki fungsi mitologis dan berhubungan 
dengan mitos Dewi Sri sebagaimana Rinding Gumbeng di Gunung Kidul Yogya, Barinding di daerah Jawa Barat, dan Robe pada etnik Ndora Kabupatan Ngada Timur Flores (Daeng, 2012).

Masyarakat Beji Ngawen Gunungkidul Yogyakarta, masih menyelenggarakan upacara Labuh yaitu upacara mulai menanam padi, sampai upacara panen yang disebut "Mboyong Dewi Sri" yang bermakna membawa Dewi Sri sebagai Dewi Padi dari sawah ke rumah. Upacara pesta panen yang lain yang masih dilaksanakan hingga kini disebut Bersih Dusun atau Sedekah Bumi atau Rasulan. Di dalam keramaian upacaranya sering dimainkan Rinding Gumbeng yang menjadi ciri khas kesenian masyarakat Beji. Alat musiknya terdiri dari Rinding dan Gumbeng yang terbuat dari bambu dan konon juga merupakan kesenian warisan dari Majapahit yang merupakan cikal bakal masyarakat setempat (Sartini, 2009).

Mitos-mitos mungkin mempunyai kedekatan satu dengan lainnya karena kesesuaian pandangan dunia masyarakat yang melatarbelakanginya. Mitos secara umum mengisahkan terjadinya berbagai peristiwa yang menyangkut hidup masyarakat, seperti lahirnya manusia pertama, terjadinya incest dan akibat-akibatnya, tumbuhnya bahan pangan bagi manusia, dan sebagainya. Atas dasar mitos ini, orang mengatur langkah tindakannya dan sejalan dengan mitos tersebut juga orang membenarkan atau menyalahkan sikapnya (Daeng, 2012). Orang Jawa menggunakan mitos untuk menjelaskan sebuah peristiwa atau keberadaan sesuatu yang ada di dunia. Kaitannya dengan naskah, bahwa dari mitos yang dipahami masyarakat boleh jadi itulah yang dituangkan dalam teks suatu naskah. Oleh karena itu, teks pada dasarnya memuat ide-ide yang bisa jadi ide itu sebagai inkarnasi makna-makna ide (Zoest, 1991). Ide atau gagasan dalam masyarakat hidup dan berkembang dalam mitos.

Mitos adalah cerita yang mengisahkan peristiwa yang berlangsung pada zaman primordial, jaman yang bukan sekarang ditinggali. Mitos menceritakan bagaimana suatu realitas ada, baik realitas secara menyeluruh, maupun hanya fragmen dari suatu 
realitas. Mitos juga dikatakan selalu merupakan cerita "penciptaan", tentang bagaimana sesuatu itu mulai ada (Widyoseputra, 1998). Salah satunya adalah mitos Ki Ageng Gribig yang dipercaya masyarakat Gribig dan peziarah yang mendatanginya. Ki Ageng Gribig merupakan orang yang ditokohkan sehingga membuat masyarakat menghormatinya dan harus melakukan peziarahan (Rachman dan Roekhan, 2012). Mitos ini mirip dengan mitos petilasan pewayangan di pegunungan Rahtawu Kudus. Masyarakat mempercayai mitos Semar. Semar dipercaya dapat berkomunikasi dengan para peziarah dan dimintai bantuani (Kumalasari, 2010). Mitos demikian ini biasanya berkaitan dengan asal-usul suatu tempat atau profil tokoh yang dianggap pernah ada di tempat tersebut.

Mitos mengarahkan pada perilaku masyarakatnya, untuk melakukan sesuatu atau tidak melakukan sesuatu. Sebagai contoh adalah mitos larangan di Puluik-puluik Selatan Kecamatan Bayang Utara Kabupaten Pesisir Selatan. Masih ada 22 jenis mitos yang dipercayai masyarakat dan 10 jenis mitos yang sudah tidak berlaku (Arlin, 2014). Mitos memberi inspirasi untuk melakukan sesuatu. Sebagai contoh, mitos Dewi Sri menginspirasi pedagang rempahrempah. Sebagai mitos, Dewi Sri dipercaya untuk menurunkan tanaman di bumi dan akhirnya memberikan inspirasi kepada para wanita untuk ikut serta menyokong kehidupan keluarga dengan berdagang rempah-rempah (Lestari, 1996). Mitos Dewi Sri juga menginspirasi kreasi dalam membuat keramik. Dewi Sri menjadi sumber ide penciptaan seni keramik yang berbentuk kendi yang merupakan wujud nilai filosofis Dewi Sri sebagai pembawa berkah. Kendi adalah tempat menampung air yang merupakan berkah bagi petani. Karya keramik kendi yang dibuat menggabungkan profil Dewi Sri dari mitos yang berkembang di masyarakat Jawa dengan modernitas sehingga tercipta karya seni. Mitos hidup dalam kebudayaan yang berkembang dinamis. Maka tidak heran mitos yang cenderung bersifat tradisional berinteraksi dengan budaya baru yang masuk ke masyarakat. 
Kebudayaan sebagai sistem budaya merupakan seperangkat gagasan yang membentuk tingkah laku seseorang atau kelompok dalam suatu ekosistem. Adaptasi mengacu pada proses interaksi antara perubahan yang ditimbulkan oleh lingkungan dari organisme tersebut (Poerwanto, 2010). Oleh karena itu, mitos sering dihubungkan dengan ajaran agama. Mitos-mitos yang dipercayai orang Jawa sesungguhnya di dalamnya terdapat nilai-nilai pendidikan tauhid, ibadah dan akhlak (Inawati, 2013). Tidak hanya yang ada di dalam alam pikiran tetapi juga yang eksplisit di dalam perkataan-perkataan orang Jawa (Jannah, 2013).

\section{MITOS SPB DI ANTARA TEORI-TEORI MITOS}

Menarik untuk dikaji, keterkaitan teori-teori tentang mitos yang dibahas oleh para ilmuwan dunia dengan mitos-mitos sebagaimana berkembang di Indonesia dan khususnya yang berkaitan dengan penciptaan tumbuhan di dalam SPB, Dewi Sri, dan implikasinya dalam gerak kehidupan masyarakat. Peran dan fungsi mitos penciptaan pada SPB dan khususnya kaitannya dengan keberadaan Dewi Sri sangat terkait dengan peran mitos yang berkembang di masyarakat. Keberadaannya sangat berpengaruh terhadap apa yang dilakukan masyarakat dan aspekaspek lain yang lebih kreatif. Oleh karenanya, fungsi mitos sebagaimana dijelaskan para pemikir terdahulu sangat tepat digambarkan oleh mitos Dewi Sri dan aspek mitos penciptaannya.

Roland Barthes menjelaskan tentang fungsi komunikasi pada mitos. Meskipun Barthes menjelaskan beberapa mitologi tempo dulu yang ada di dunia Barat, tetapi fungsinya tidak jauh beda dengan mitos yang ada di Indonesia. Barthes menghubungkan mitos dengan bahasa. Mitos merupakan suatu sistem komunikasi, dan sejatinya mitos adalah pesan (Barthes, 2015). Menurutnya, sebagai tipe wicara, segala sesuatu bisa menjadi mitos sejauh disajikan sebagai sebuah wacana. Sesuatu yang ada di dunia dapat berubah dari sesuatu yang diam menuju keberadaan oral yang terbuka untuk ditafsirkan masyarakat. Tidak ada hukum yang melarang orang membicarakan sesuatu. Sebagai suatu bentuk 
komunikasi, mitos tidak ditentukan oleh objek pesannya tetapi bagaimana cara mengutarakan pesan tersebut. Meskipun mitos memiliki batas-batas formal, tetapi dianggap tidak substansial (Barthes, 2015). Mitos bersifat terbuka dan berkembang sesuai dengan pemahaman dan interpretasi masyarakatnya.

William Bascom menjelaskan hubungan mitos, bahasa dan wacana. Ia menjelaskan mitos dalam rangka penelusurannya mengenai bentuk-bentuk folklor sebagai prosa naratif. Mitos dipandangnya sebagai suatu prosa naratif yang hidup di dalam suatu masyarakat. Prosa-prosa naratif tersebut diceritakan dan dianggap sebagai cerita kebenaran pada masa lampau. Mitos diterima sebagai suatu kepercayaan, diajarkan untuk dipercayai, dan mitos dapat dIambil sebagai otoritas dalam menjawab ketidaktahuan, ketidakpastian, dan ketidakpercayaan. Mitos merupakan pengejawantahan dari dogma-dogma yang biasanya bersifat sakral dan diasosiasikan dengan teologi dan ritual. Aksiaksinya berada dalam kerangka awal dunia, ketika dunia waktu itu berbeda dengan waktu kini. Dunia tersebut adalah dunia yang lain, dunia langit atau dunia bawah. Mitos-mitos menceritakan asal-usul dunia, umat manusia, kematian, karakteristik burung-burung, binatang-binatang, keistimewaan-keistimewaan geografik, dan fenomena alam. Mitos-mitos di antaranya menceritakan tentang aktivitas dewa-dewa, kisah percintaaan mereka, hubungan kekeluargaannya, persahabatan dan permusuhannya, kejayaan dan kekalahannya (Bascom, 1965).

Penjelasan Bascom sangat sesuai dengan cerita penciptaan pada SPB. Di dalam naskah tersebut diceritakan kisah-kisah para dewa, asal-usul dewa-dewi, kisah percintaan, karakter binatang, hubungan dunia kahyangan dan dunia, asal-usul dunia, awal mulai penciptaan, dan lainnya. Mitos penciptaan tersebut akhirnya terfokus pada mitos Dewi Sri. Mitos ini, ternyata hidup dalam pikiran masyarakat dan menjadi cerita lisan. Selanjutnya cerita mitos tersebut terpaparkan dalam banyak naskah yang ditulis oleh para pujangga dan tentu saja menjadi bahan cerita dalam berbagai pertunjukan wayang. Konkritnya, bahkan cerita mitos Dewi Sri 
menjadi semacam cerita ritual karena di dalam perhelatan ritual masyarakat yang berkaitan dengan pertanian, cerita Dewi Sri menjadi cerita yang harus dipentaskan. Mitos Dewi Sri menjadi suatu media komunikasi antargenerasi dan berkaitan dengan kepercayaan. Hal ini sesuai dengan pandangan bahwa kebanyakan cerita dapat dikategorikan sebagai mitos ketika cerita-cerita tersebut berhubungan dengan yang supranatural dan yang misterius. Terdapat dua prinsip suasana hati dalam mitos, yaitu: kerinduan, keinginan di sisi yang satu dan ketidakmudahan, ketakutan. Mitos memanfaatkan konsep-konsep religius dan kepercayaankepercayaan bahkan ketika hal tersebut sebetulnya bukan sesuatu yang tidak "religius" (Bascom, 1965). Mitos dikategorikan sebagai cerita dengan isi emosional yang tinggi dan secara khusus membawa pada agama atau kepercayaan. Mitos bahkan harus disampaikan dengan diulang-ulang, kemudian diterapkan dalam banyak hal dan sering diterima sebagai kebenaran absolut (Bascom, 1965). Inilah yang terjadi pada acara-acara ritual masyarakat petani di Jawa dan Indonesia pada umumnya. Oleh karena itu maka mitos menjadi cerita yang berisi pesan bermakna.

Apa yang dimiliki dan dilakukan oleh manusia pada umumnya diturunkan dari mitos. Mitos merupakan cerita-cerita pencarian kebenaran, makna, dan signifikansi sepanjang masa. Manusia membutuhkan untuk menceritakannya dan memahaminya. Manusia memerlukan pemahaman tentang kematian dan berbuat apa dengan kematian tersebut. Manusia juga membutuhkan bantuan-bantuan dalam fase-fase kehidupan dari kelahiran sampai kematian. Manusia membutuhkan kehidupan untuk menandai, menyentuh yang abadi, memahami yang misterius, dan menemukan siapa dirinya. Mitos merupakan tandatanda dari potensialitas kehidupan manusia yang spiritual. Mitos merupakan pencarian makna dan pengalaman tentang makna (Campbell dan Moyers, 1988). Mitos-mitos berperan membawa pesan dan kebijaksanaan hidup.

Menurut Campbell, setiap individu harus menemukan mitos-mitos yang berhubungan dengan kehidupannya sendiri. 
Kehidupan meliputi banyak hal sehingga mitos pada dasarnya melayani empat fungsi sekaligus yaitu fungsi mistis, fungsi kosmologis, fungsi sosiologis dan fungsi pedagogi. Fungsi mistik yaitu adanya kesadaran dan kekaguman atas misteri-misteri di alam dan manusia mengarahkan misteri-misteri yang transenden pada kondisi-kondisi dunia aktual. Fungsi kosmologis berkaitan dengan bagaimana bentuk dunia, suatu proses bagaimana misteri tersebut muncul yang sesungguhnya. Sedangkan fungsi sosiologis artinya bahwa mitos mendorong dan mengabsahkan suatu tata sosial tertentu. Mitos berfungsi menjadi bagian dari hukum etik yang akan menentukan masyarakat yang baik yang diinginkan. Fungsi pedagogik berkaitan dengan fungsi belajar dan beradaptasi. Manusia harus mengikuti pola hidup di lingkungannya dan melakukan adaptasi seperlunya sehingga manusia dapat hidup dengan harmonis bersama alam dan lingkungan sosialnya. Mitos menjadi penghubung antara dunia atas dan dunia nyata, dan kegiatan di alam mencerminkan penghargaan atas eksistensinya (Campbell dan Moyers, 1988).

Oleh karena itu, mitos, simbol, ritus, dan ucapan merupakan manifestasi dari metafisika kuno yang biasanya tidak dirumuskan dalam bahasa yang teoritis. Diperlukan pemahaman dan penerjemahan dalam bahasa sehari-hari. Ketika seseorang tidak mampu memaknainya maka orang tersebut menunjukkan kesadaran akan situasi tertentu dalam kosmos dan hal tersebut mengimplikasikan pada sikap metafisis. Simbol dan mitos dianggap sebagai pengungkapan konsep-konsep metafisis tentang ada, tiada, tidak nyata, khayal sehingga muncullah benda-benda di alam yang dianggap suci atau tempat bersemayamnya roh (Mircea, 2002). Atas dasar inilah maka sebagian masyarakat memiliki pemahaman tertentu mengenai suatu tempat dan melalukan sesuatu atau tidak melakukan sesuatu sesuai dengan pemahamannya tersebut.

Kenyataan adanya hal yang suci dan dimuliakan tersebut menjadi penyebab adanya kegiatan-kegiatan manusia dalam realitas. Sesuai perjalanan sejarahnya, manusia akan meneruskan 
dengan pengulangan-pengulangan. Kegiatan manusia dalam realitas merupakan pengulangan secara terus-menerus dari apa yang sudah diawali orang lain. Itulah yang sering disebut dengan tradisi. Maka prinsip sebuah fakta bagi manusia kuno merupakan fungsi imitasi atas arketipe surga (langit). Dijelaskan bahwa imitasi ini selanjutnya dikuatkan melalui partisipasi dalam "simbolisme Pusat" dari suatu kota, kuil, atau rumah yang diasosiasikan sebagai "pusat dunia". Konsep imitasi dan pusat dunia ini kemudian dimaterialisasi maknanya dalam tindakan-tindakan riil sebagai pengulangan tindakan para dewa, pahlawan atau leluhur (Mircea, 2002). Bumi yang ditempati manusia sekarang merupakan duplikat dari bumi di langit. Setiap kebajikan yang dilakukan di dunia merupakan tiruan dunia langit (Mircea, 2002). Oleh karena itu, menjadi masuk akal mengapa terdapat tempat-tempat yang disucikan, dihormati, dan sebagian dianggap sebagai permulaan sejarah manusia. Mungkin hal tersebut riil adanya, ataukah sesungguhnya sesuatu yang menjadi mitos saja.

Selain yang sudah dijelaskan di bagian sebelumnya, ternyata aktivitas lain dalam bentuk kesenian juga dapat bersumber dari mitosnya sendiri. Hal ini dapat menjelaskan mengapa keseniankesenian seperti Karinding, wayang kulit dengan cerita Dewi Sri, Rinding Gumbeng dan lainnya menjadi bagian dari ekspresi penghormatan atas mitos Dewi Sri.

Menurut Mircea Eliade, setiap aktivitas dunia kuno merupakan bagian cara berpartisipasi dalam kesucian. Aktivitas profan bagi manusia kuno adalah aktivitas yang tidak ada contohnya dalam dunia mitis, yaitu kegiatan yang tidak memiliki model yang dicontoh dari cerita dunia langit, maka setiap kegiatan yang bertujuan tertentu dianggap oleh manusia kuno sebagai ritual. Sebagai contoh, sebuah tari merupakan suatu model ekstrahuman. Tarian tersebut merupakan model ilahiah yang mungkin diciptakan oleh pahlawan suatu masyarakat, dan selanjutkan diturunkan secara terus-menerus untuk tujuan tertentu. Tujuannya misalnya untuk mendapatkan makan, menghormati orang mati, atau menjamin tertib kosmos. Tarian tersebut bisa ditampilkan dalam 
peristiwa inisiasi, upacara magis-religius, perkawinan, dan lainnya. Gerak-gerak tari biasanya meniru gerak-isyarat arketipe atau peringatan gerakan mitis. Tari yang dilakukan pada suatu saat riil merupakan pengulangan, reaktualisasi dari suatu "hari itu" atau illud tempus (Mircea, 2002) Hal ini menunjukkan bahwa ontologi "primitif" memiliki struktur Platonik (Mircea, 2002) Kenyataannya, imitasi, pengulangan, ritual, kesenian, dan lainnya terjadi sampai saat ini. Kiranya, istilah kuno perlu diberikan batasannya sendiri.

Bagi manusia primitif, regenerasi waktu bersifat terusmenerus. Maka diperlukanlah mitos yang berhubungan dengan bulan yang akan diikuti dengan pemahaman tentang kematian dan kebangkitan kembali, kesuburan dan regenerasi, inisiasi, dan sebagainya (Mircea, 2002). Sejarah dianggap sebagai teofani. Sebagai contoh misalnya bencana yang datang kepada suatu kaum, dipercaya sebagai hukuman yang diberikan dewa. Suatu peristiwa historis memerlukan penjelasan religius sehingga suatu peristiwa bencana besar tampak sebagai hukuman yang diberikan Tuhan. Bagi dunia Timur, peristiwa tersebut tidak hanya memerlukan makna tetapi setiap peristiwa mempunyai maknanya sendiri. Peristiwa tersebut merupakan koherensi tersembunyi melalui pembuktian sebagai ungkapan konkret atas kehendak ilahi (Mircea, 2002).

Dengan pola strukturaliasmenya, Clyde Levi-Strauss menjelaskan bahwa terdapat suatu tatanan yang tidak kelihatan yang tersembunyi dari suatu hamparan fenomena, kenyataan kebudayaan yang bervariasi. Levi-Strauss berupaya untuk menyingkapkan tatanan sejumlah aturan (sistem, struktur, dan lainnya) di dalam banyak adat-istiadat yang mengangkut sistem kekerabatan, perkawinan dan cerita mitologi yang kelihatannya tanpa arti. Menurutnya, sesuatu yang tampak irasional dan keragaman yang kacau-balau mengganggu akal manusia dan membutuhkan keteraturan. Levi-Strauss berpendapat bahwa universum realitas sesungguhnya tidaklah kacau-balau, melainkan mengandung tata aturan tertentu. Tata aturan inilah yang diungkapkan oleh manusia melalui akal-budinya, baik lewat akal 
pikiran ilmiah yang dianggap "jinak" maupun melalui jalan pemikiran mitos yang dianggap "liar" (Levi-Strauss, 1997).

Mitos dan implikasi mitos pada kehidupan masyarakat, yang menumbuhkan pola-pala ritual, pola berkesenian, dan pola berkebudayaan secara sistemik di dalam masyarakat menunjukkan fungsi mitos sebagaimana dijelaskan Peursen. Menurut Peursen (1992), mitos merupakan sebuah cerita yang memberikan pedoman dan arah tertentu pada sekelompok orang. Mitos dalam suatu kelompok masyarakat dapat berwujud cerita yang berkembang dari mulut ke mulut atau dalam bentuk budaya yang lain seperti tari atau pementasan wayang. Inti cerita mitos dapat berupa lambanglambang yang mencetuskan pengalaman manusia purba seperti lambang kebaikan dan kejahatan, hidup dan kematian, dosa dan penyucian, perkawinan dan kesuburan, atau surga dan akhirat. Mitos bukanlah cerita biasa yang menggambarkan suatu peristiwa, tetapi mitos merupakan cerita yang juga memberikan arah kepada kelakuan manusia dan merupakan sejenis pedoman untuk hidup manusia yang lebih bijaksana. Melalui mitos, manusia berpartisipasi dalam kejadian-kejadian sekitarnya, menanggapi daya-daya kekuatan alam, dan manusia menjadi bagian tak terpisahkan. Manusia belum dapat memposisikan dirinya menjadi subjek dan alam sebagai objek. Selanjutnya, Peursen menyimpulkan bahwa setidaknya mitos mempunyai tiga fungsi: menyadarkan manusia bahwa terdapat kekuatan-kekuatan ajaib, memberikan jaminan bagi masa kini, dan menjadi pengantara antara manusia dan daya-daya kekuatan alam. Mitos membantu manusia untuk menghayati daya-daya mitis sebagai kekuatan yang dapat menguasai alam dan kehidupan komunitasnya. Cerita mitos mementaskan kejadian masa lampau dengan harapan bahwa hal tersebut juga akan terjadi di masa kini seperti cerita tentang kesuburan diungkap kembali pada acara ritual pada awal musim tanam, perburuan atau kegiatan lainnya. Dengan dikembangkannya cerita tersebut maka alam gaib akan meresapi dunia sehari-hari. Mitos berfungsi untuk pengantara antara manusia dan daya-daya kekuatan alam. Mitos memberikan 
pengetahuan tentang dunia pada manusia primitif untuk memperoleh keterangan-keterangan. Mitos memberikan keterangan kepada manusia mengenai terjadinya dunia (kosmogoni, yaitu cerita tentang penciptaan langit dan bumi), hubungan antara dewa-dewa (theogoni, yaitu cerita tentang terjadinya dewa-dewa), asal-usul kejahatan. Ketiga fungsi mitos secara bersama menciptakan strategi yang menyeluruh, mengatur dan mengarahkan hubungan antara manusia dan daya-daya kekuatan alam (Peursen, 1992). Ketiga hal tersebut nampak juga terjadi pada manusia sekarang dengan adanya mitos penciptaan dan Dewi Sri yng implikasinya masih tumbuh dalam kehidupan masyarakat pendukungnya.

Dari pembacaan teori mitos di atas, dapat dipahami bahwa mitos di dalam SPB secara keseluruhan termasuk mitos penciptaannya, mitos-mitos lain tentang kesuburan yang berkaitan dengan Dewi Sri dan mitos-mitos lain yang tersebar luas di masyarakat, dapat menjadi sumber belajar yang kaya. Filsafat yang mempunyai objek kajian yang luas mempunyai peran untuk mengeksplorasi mitos-mitos tersebut.

\section{KAJIAN FILSAFATI PADA MITOS SPB Kajian Filsafati Berdasar Cabang Filsafat}

Filsafat mengkaji banyak bidang. Disebutkan bahwa kerangka pembicaraan persoalan filsafat meliputi pandanganpandangan dalam filsafat dan pemikiran-pemikiran yang tumbuh di sekitar agama baik di Barat maupun Timur, masalah-masalah dasar terkait manusia dan kajian tentang nilai (Titus, Smith, dan Nolan, tanpa tahun). Sedangkan Kattsoff memberikan kerangka bidang-bidang kajian filsafat secara lebih detail terkait dengan: makna kebenaran, ontologi, kosmologi masalah hidup, masalah jiwa, aksiologi (nilai), etika, estetika, masalah, manusia, politik, juga hal agama. Oleh karena itu, sesungguhnya ruang kajian filsafat sangat luas (Kattsoff, 1996).

Dari materi yang ada di dalam SPB maka dapat dieksplorasi banyak kajian. Ontologi sebagai kajian tentang yang-ada dan yang- 
tidak ada, tentang kenyataan (Kattsoff, 1996), dapat dilakukan terkait unsur kehidupan kahyangan dan dunia, tentang dewa dan manusia, tentang penitisan dan lainnya. Kosmoslogi sebagai kajian tentang ruang, waktu dan gerakan (Kattsoff, 1996), juga dapat dipakai sebagai perspektif untuk mengeksplorasi konsep ruang waktu yang tergambar di dalam cerita. Ruang waktu alam kedewaan dan keduniaan menjadi dua hal yang bersama ada dan mengatur gerakan dewa dan manusia dalam cerita mitos tersebut. Etika sebagai kajian tentang baik-buruk (Kattsoff, 1996) juga memungkinkan untuk menjawab perilaku para dewa dan manusia. Mungkin tidak semata-mata gambaran asmara para dewa, kematian, penghukuman dan lainnya, tetapi sesungguhnya di dalamnya terkandung maksud tersembunyi yang dapat dipetik dari cerita tersebut. Dari sisi penciptaan tetumbuhan pada mitos Dewi Tisnawati dan akhirnya memunculkan pandangan, ritual, dan seni terkait dengan mitos tersebut di masyarakat, dapat digali hal yang berkaitan dengan bagaimana asal-usul pengetahuan tersebut muncul. Epistemologi berkaitan dengan metode memperoleh pengetahuan (Kattsoff, 1996).

Masih banyak fokus kajian filsafat dapat dilakukan misalnya terkait dengan teori pandangan dunia, masalah manusia, masalah jiwa, masalah nilai, atau masalah ketuhanan. Kajian berbasis nilainilai kearifan lokal juga dapat dikembangkan karena implementasi mitos di masyarakat dalam wujudnya kemudian akan sangat tergantung pada bagaimana masyarakat memaknai dan menjalankannya. Kearifan lokal sebagai gagasan setempat yang dianggap baik, bijaksana (Sartini, 2004) dan dimiliki oleh masyarakat pendukungnya akan menampilkan implementasi dan dampak sosial budaya yang berbeda dari setiap masyarakat. Hal ini juga merupakan ruang untuk mengapresiasi kekayaan kebudayaan dan menghargai kebudayaan masyarakat lain karena sesungguhnya akan lebih objektif melihat suatu kebudayaan dari sistem nilai yang ada dalam kebudayaan suatu masyarakat itu sendiri (Poerwanto, 2010). 


\section{Kajian atas Dasar Karakteristik Metode Kajian Filsafat}

Kajian filsafat dalam hal ini dapat dipahami sama dengan memahami sebuah tulisan atau karangan filsafat sebagaimana yang dijelaskan oleh Woodhouse (2005). Ciri sebuah karangan filsafat adalah sebuah tulisan yang sifatnya kritis. Kritis dalam hal ini berarti bahwa tulisan filsafat bukanlah laporan atau tulisan yang bersifat reportif. Tulisan reportif hanya bersifat menata dan mengulang informasi tentang pemikiran orang lain, sedangkan tulisan filsafati haruslah mengandung argumen atau pemikiran sendiri. Dukungan rasionalitas merupakan sesuatu yang penting di dalam tulisan filsafat. Ketika suatu teks filsafat tersusun atas argumen tertentu, maka penulis selanjutnya haruslah mempertanyakan argumen penulis pertama tersebut. Selanjutnya Woodhouse mengajukan beberapa format kajian filsafat yang kritis tersebut, yaitu: memperbandingkan atau mempertentangkan dua teori atau lebih; mengritik sebuah teori atau argumen; mempertahankan pandangan seorang filsuf untuk melawan kritik yang keliru dan mendukung teori temuan sendiri (Woodhouse, 2005). Apa hubungannya dengan mitos, realitas budaya umumnya, dan khususnya naskah sebagai objek kajian filsafat?

Suatu naskah ditulis atas dasar logika berpikir tertentu. Dalam kaitannya dengan naskah atau teks sebagaimana SPB dan naskah lainnya ada beberapa hal yang harus dicermati. Pertama, sesungguhnya bila akan ditilik sebagaimana objek kajian filsafat dalam pemikiran Woodhouse maka naskah tersebut harus diposisikan sebagai objek, yaitu karya filsuf atau pemikir. Artinya, penulis naskah (eksplisit atau tidak) harus diposisikan sebagai pemikir. Kedua, isi karya tersebut harus ditulis dalam bentuk argumen-argumen ketimbang sebagai cerita. Pemikiran di balik cerita harus dijadikan sebagai suatu paparan argumen. Hal ini tentu saja memerlukan interpretasi mendalam dan tentu saja di dalam naskah tersebut terdapat banyak substansi argumen yang dapat dieksplorasi. Dalam hal ini, dapat dipakai pendekatan-pendekatan kajian filsafat sebagaimana dijelaskan pada bagian sebelumnya. 
Aspek ontologi, kosmologi, etika, estetika, manusia dan lainnya harus diafirmasikan sebagai suatu paparan argumen terlebih dahulu. Setelah hasil paparan argumennya dapat dipahami, baru dilakukan analisis kritis dengan mempertanyakan basis argumen yang dibuat. Mungkin peneliti akan memperkuat argumennya dengan alasan-alasan baru, menolak atau membandingkannya dengan argumentasi yang lain.

Ada banyak perspektif dapat dipakai untuk mengkerangkai kajian tentang mitos dan khususnya mitos penciptaan dan mitosmitos lain yang terdapat pada Serat Purwakandha Brantakusuman. Di samping itu, terdapat beberapa langkah yang harus ditempuh ketika peneliti ingin menjelaskannya sebagaimana karakteristik kajian filsafati sebagaimana yang dimaksud oleh Woodhouse. Metode mengkaji ini juga dapat dilakukan pada objek penelitian lain.

\section{SIMPULAN}

Mitos penciptaan yang dijelaskan dalam SPB terkait dengan penciptaan tetumbuhan berlatarkan pada cerita kematian Dewi Tisnawati yang kemudian di buang ke bumi. Jasad Dewi Tisnawati kemudian memunculkan banyak tanaman yang tumbuh dari bagian-bagian tubuhnya. Pada bagian lain di awal Pupuh dijelaskan mengenai asal-usul kerajaan di Jawa dengan rajanya yang awal dan kemudian rajanya yang dapat menjadikan kerajaannya hebat yaitu Raja Makukuhan. Mitos ini bila ditelusur kemungkinan berhubungan dengan legitimasi sosial-politik-budaya seorang raja di Jawa.

Dari banyak kajian, belum ditemukan kajian yang menjelaskan mitos tentang asal-usul tetumbuhan meskipun banyak penelitian yang ditemukan terkait pertanian dan mitos Dewi Sri. Implikasi pengaruh mitos tersebut dalam kehidupan dan aktivitas manusia, bentuk-bentuk ritual dan aktivitas sosial-budaya, kesenian, dan lainnya juga menjadi perhatian peneliti. Kajian tentang mitos yang lain lebih banyak terkait dengan asal-usul suatu 
lokasi yang kemudian menjadikan wilayah/lokasi tersebut sebagai tempat yang dianggap sakral dan perlu diziarahi.

Mitos dalam SPB dan mitos-mitos yang terdapat dalam banyak kajian mendukung konsep-konsep mitos yang sudah dijelaskan para pemikir besar seperti Eliade, Barthes, Bascom, Campbell, Levi-Strauss, dan Peursen, baik dari sisi esensi maupun fungsinya dalam kebudayaan dan masyarakat.

Mitos penciptaan, mitos-mitos yang lain dalam SPB, dan mitos-mitos yang ditemukan di Indonesia umumnya, dapat menjadi bahan kajian dari banyak perspektif cabang-cabang ilmu filsafat. Substansi nilai yang ditawarkan oleh penulis naskah yang memuat cerita mitos juga dapat dikritisi dengan mengikuti jenjang langkah-langkah filsafati untuk mendapatkan kajian filsafat secara kritis.

\section{DAFTAR PUSTAKA}

Arlin, Riri Yuberko. 2014. "Mitos Larangan di Kanagarian PuluikPuluik Selatan Kecamatan Bayang Utara Pesisir Selatan Kajian Teori Fungsi". Skripsi Universitas Andalas, scholar.unand.ac.id.

Bakker, Anton, dan Achmad Charris Zubair. 1994. Metodologi Penelitian Filsafat. Yogyakarta: Liberty.

Barthes, Roland. 2015. Mitologi. Yogyakarta: Kreasi Wacana.

Bascom, William. 1965. "The Forms of Folklore: Prose Narratives". American Folklore Society 78 (307): 3-20.

Campbell, Joseph, dan Bill Moyers. 1988. The Power of Myth. New York: Doubleday.

Couteau, Jean. 2010. "Watugunung dan Oedipus Sang Raja sebagai Mitos tentang Waktu yang Melampaui Waktu". Jurnal Filsafat 20 (1): $27-43$.

Daeng, Hans J. 2012. Manusia Kebudayaan dan Lingkungan Tinjauan Antropologis. Cetakan Keempat. Yogyakarta: Pustaka Pelajar.

Fitria, Vita. 2012. “Interpretasi Budaya Clifford Geertz: Agama sebagai Sistem Budaya. Sosiologi Reflektif 7 (1): 57-64. 
Geertz, Clifford. 1993. "Religion as a Cultural System". https://isites.harvard.edu/fs/docs/icb.topic152604.files/Week _4/Geertz_Religon_as_a_Cultural_System_.pdf.

Hartati, Sri Trisna Dewi. 2012. "Peranan Dewi Sri dalam Pertanian Indonesia". Makalah Ikatan Ahli Arkeologi Indonesia, Universitas Udayana, dalam Http://aiaipusat.wordpress. com/20120.

Inawati, Dewi. 2013. “Nilai-Nilai Pendidikan Islam dalam Mitos Jawa (Studi Kasus di Dusun Pilang Desa Tejoasri Kecamatan Laren Kabupaten Lamongan". Skripsi UIN Sunan Ampel Surabaya. digilib.uinsby.ac.id/10873.

Jannah, M. 2013. “Nilai-Nilai Pendidikan Islam dalam Perkataan Mitos Budaya Jawa". Skripsi UIN Sunan Ampel Surabaya. digilib.uinsby.ac.id/10892.

Kattsoff, Louis O. 1996. Pengantar Filsafat. Cetakan Ketujuh. Yogyakarta: Tiara Wacana.

Kumalasari, Dyah. 2010. "Mitos Petilasan Semar di Pegunungan Rahtawu Kudus dalam Kajian Foklor". Skripsi Fakultas Bahasa dan Seni Universitas Negeri Semarang. lib.unnes.ac.id/9816.

Lestari, Nanny Sri. 1996. "Mitos Dewi Sri dan Rempah-Rempah (Sebuah Penelitian Terhadap Kepercayaan pada Mitos Dewi Sri yang Dikenal oleh Perempuan Jawa yang Berjualan Rempah-Rempah di Pasar)". Laporan Penelitian Universitas Indonesia. http://lib.ui.ac.id/abstrakpdf?id= 76633\&lokasi $=$ lokal.

Levi-Strauss, Claude. 1997. Mitos, Dukun E Sihir. Cetakan Pertama. Yogyakarta: Kanisius.

Luwiyanto. 2018. "Analisis Mitos Flora dan Fauna dalam Serat Purwakandha Brantakusuman Pupuh XVI-XXXIII Disertai Suntingan Teks dan Terjemahannya. Laporan Penelitian Universitas Widya Dharma.

Masroer Ch. Jb. 2004. The History of Java: Sejarah Perjumpaan AgamaAgama di Jawa. Cetakan Pertama. Yogyakarta: Ar-Ruzz Jogjakarta. 
Mircea, Eliade. 2002. Mitos Gerak Kembali yang Abadi, Kosmos dan Sejarah. Yogyakarta: Ikon Teralitera.

Peursen, C.A. Van. 1992. Strategi Kebudayaan (Stretegie van de Cultuur). Cetakan Ketiga. Yogyakarta: Kanisius.

Poerwanto, Hari, 2010, Kebudayaan dan Lingkungan dalam Perspektif Antropologi, Pustaka Pelajar, Yogyakarta.

Rachman, Doni, and Yuni Pratiwi Roekhan. 2012. “Kajian Mitos Masyarakat terhadap Foklor Ki Ageng Gribig". Skripsi Universitas Negeri Malang, karya-ilmiah.um.ac.id/index. php/ sastra-indonesia/article.

Saputra, Heru Setya Puji. 2007. Memuja Mantra: Sabuk Mangir Dan Jaran Goyang Masyarakat Suku Using Banyuwangi. Cetakan 1. Yogyakarta: LKiS.

Sartini. 2004. "Menggali Kearifan Lokal Nusantara Sebuah Kajian Filsafati". Jurnal Filsafat 37 (2): 111-20.

- - . 2009. “Kearifan Ekologis sebagai Implementasi Pandangan Organistik Holistik (Studi Kasus Masyarakat Hutan Adat Wonosadi Ngawen Gunung Kidul)". Laporan Penelitian Fakultas Filsafat UGM.

- - - . 2012. "Nilai-Nilai Kearifan Lokal pada Hubungan Antara Mitos Dewi Sri dan Eksistensi Seni Tradisional di Indonesia". Laporan Penelitian pada Fakultas Filsafat Universitas Gadjah Mada Yogyakarta.

- - - 2016. "Mitos: Eksplorasi Definisi dan Fungsinya dalam Kebudayaan". Laporan Penelitian Fakultas Filsafat UGM Yogyakarta.

Subiyantoro, Slamet. 2009. "Pengembangan Model Pelestarian Nilai

Keharmonisan dalam Tata Hidup sebagai Upaya Menunjukkan Ketahanan Lingkungan Sosial Budaya Masyarakat Jawa Melalui Pemahaman Tentang Simbolisme Patung Loro Blonyo". Laporan Penelitian Hibah Bersaing, UNS Surakarta.

Suciani, Indah. 2015. "Ritual Cupu Kyai Panjolo Dan Perubahan Sosial Masyarakat Dusun Mendak, Grisekar, Panggang, Gunung Kidul”. Skripsi Jurusan Sosiologi Agama Fakultas 
Ushuluddin dan Pemikiran Islam UIN Sunan Kalijaga Yogykarta.

Sumintarsih. 2007. "Dewi Sri dalam Tradisi Jawa”. Jantra II (3): 13644.

Sutrisno, Mudji. 2008. Filsafat Kebudayaan: Ikhtiar Sebuah Teks.

Cetakan 1. Jakarta: Hujan Kabisat.

Suwardi. tanpa tahun. "Makna Simbolik Mitos Dewi Sri dalam Masyarakat Jawa Kajian Model Linguistik Levi-Strauss". Linguistika 16 (31).

Titus, Harold H., Marilyn S. Smith, dan Richard T. Nolan. tanpa

tahun. Persoalan-Persoalan Filsafat (Living Issues in

Philosophy. Jakarta: Bulan Bintang.

Waryanti, Dessy Rachma. 2015. “Figur Dewi Sri dalam Mitos

Masyarakat Jawa sebagai Sumber Ide Penciptaan Karya Seni

Keramik" Universitas Sebelas Maret.

eprints.uns.ac.id/18297/.

Widyoseputra, Manu J. 1998. “Serat Purwakandha: Sebuah Teks

Babad dari Kraton Yogyakarta". Naskah disajikan dalam

Simposium Pernaskahan Nusantara II Kampus UI Depok.

Woodhouse, Mark W. 2005. Berfilsafat Sebuah Langkah Awal (A Preface

to Philosophy). Cetakan Keenam. Yogyakarta: Kanisius.

Yuliawan, Kasmahidayat. tanpa tahun. "Seni Pertunjukan Ritual

Cermin Hakikat Hidp Masyarakat Religius Banten Selatan".

Laporan Penelitian, dalam Http://lppm.upi.edu/penelitian/ abstract/ Yuliawan.

Zoest, Aart van. 1991. Fiksi dan Non Fiksi dalam Kajian Semiotik. Jakarta: Intermasa. 